\title{
Economic growth and carbon emission in China: a spatial econometric Kuznets curve? ${ }^{* 1}$
}

\author{
Hengzhou $X u^{2}$, Chuanrong Zhang ${ }^{3}$, Weidong $\mathrm{Li}^{4}$, Wenjing Zhang ${ }^{5}$, \\ Hongchun Yin $^{6}$
}

\begin{abstract}
Economic development has largely contributed to the increment of $\mathrm{CO}_{2}$ emission. This study uses spatial econometric models to investigate the relationship between economic growth and carbon emission in China with data of 30 provinces of China during the period of 2000 to 2012. Results show that the relationship between carbon emission and economic growth in China during the recent decade has the development tendency toward an inverse U-shaped curve, approximately confirming the carbon emission's Kuznets curve hypothesis in China. There exists a significant spatial correlation between carbon emission and economic growth,
\end{abstract}

* Received: 12-10-2017; accepted: 11-06-2018

1 This research has been supported by National Social Science Foundation of China: "Evaluation on Effect of Rural Land Rights Confirmation Policy Implementation under the Perspective of Household Livelihood Diversity" (Grants: 17BJY090) and Humanities and Social Sciences projects of the Ministry of Education "Farmers' behavior response to farmland ownership and its impact on rural land transfer" (Grants: 16YJC630149).

2 Associate Professor, Tianjin University, College of Management and Economics, No. 92 Weijin Road, Tianjin, P.R. China. Scientific affiliation: resources economics and policy. Phone: +086 22 27403971.E-mail: xuhengzhou@163.com.

${ }^{3}$ Full Professor, University of Connecticut, Department of Geography, Storrs, CT 062694148, USA. Scientific affiliation: land use and policy. Phone: +086 22 27403971. E-mail: Cindyzhang2003@126.com.

4 Full Professor, University of Connecticut, Department of Geography, Storrs, CT 062694148, USA. Scientific affiliation: land use and policy. Phone: +086 22 27403971. E-mail: weidongli2003@126.com.

5 Master student, Tianjin University, College of Management and Economics, No. 92 Weijin Road, Tianjin, P.R. China. Scientific affiliation: land economics and policy. Phone: +086 22 27403971.E-mail:wenjingzh@tju.edu.cn.

${ }^{6}$ Associate Professor, Tianjin University, College of Management and Economics, No. 92 Weijin Road, Tianjin, P.R. China. Scientific affiliation: resources economics and policy. Phone: +086 22 27403971.E-mail: hongchunyin2012@163.com (corresponding author). 


\begin{abstract}
implying that carbon emission in a province may be influenced by economic growth in adjacent provinces. When economic growth reaches 279.91 million Yuan $/ \mathrm{km}^{2}$ GDP (at a comparable price in 2000), the contradiction between economic growth and carbon emission begins to be gradually alleviated. These findings provide new insights and valuable information for reducing carbon emissions in China.
\end{abstract}

Key words: Carbon emission, environmental Kuznets curve, land-use change, spatial econometrics

JEL classification: $Q 56$

\title{
1. Introduction
}

The increasing severity of global warming has resulted in a significant damage to the environment (Wallace et al., 2014). Due to the rapid development of the economy over the past 30 years, carbon emission in China is ranked the highest in the world now and is still increasing rapidly. According to the greenhouse gas inventory of the Intergovernmental Panel on Climate Change (IPCC), changes in how and where carbon is stored in terrestrial ecosystems are very important to global carbon cycle and global warming (Zhao, 2011). In 2000-2005, terrestrial ecosystems absorbed $0.9 \mathrm{Pg} / \mathrm{a}$ carbon, of which $12.5 \%$ is attributed to carbon emissions from energy consumption and cement production (Lal, 2002). Barnett et al. (2005) reported that approximately one-fourth of anthropogenic carbon dioxide emissions were caused by land-use changes in the world, and the rest were caused mainly by the combustion of fossil materials.

Over the past decades, a considerable number of studies have been focused on the impact of economic growth on the environment. Scholars in this field have been trying to determine whether environmental pressure is rising at low income levels but falling at high income levels because of the increasing national income. If such a phenomenon occurs, an inverted U-shaped relationship between economic growth and environmental quality should exist. This inverted U-shaped relationship curve between economic growth and environmental quality is known as the environmental Kuznets curve (EKC) (Culas, 2007), because such a relationship curve was first discovered by Kuznetz in his studies on the relationship between income and inequality during an agrarian-industrial transition of a regional economy (Galbraith, 2007). Since the early 1990s, heated discussions on the EKC hypothesis have ensued (Stern, 1998, 2004, 2012, 2014), and there are a number of publications to test this hypothesis (Carson, 2010; Fodha and Zaghdoud, 2010; Kijima et al., 2010; He and Richard, 2010; Shahbaz et al., 2012). For example, this hypothesis has been evaluated by considering various environmental degradation indicators, including deforestation (Bhattarai and Hammig, 2001; Culas, 2007), carbon emission (Dinda, 2001; Romero-Avila, 2008; Iwata et al., 2010; Fosten et al., 2012; Saboori et al., 2012), sulfur dioxide 
emission (Kaufmannetal., 1998; Leitao, 2010) and municipal waste (Koop and Tole, 1999). However, empirical studies about the relationship between $\mathrm{CO}_{2}$ emission and economic growth have not reached a clear conclusion, not like the case with air and water pollutants. Although some studies found a linear linkage between $\mathrm{CO}_{2}$ emission and per capita income (Azomahou et al., 2006), others reported an inverted U-shaped Kuznets curve relationship (Apergis and Payne, 2009; Lean and Smyth, 2010) or even an N-shaped curve between them (Grossman and Krueger, 1995).

Most studies used panel or cross-section data to analyze the relationship between economic development and environmental pollution for a group of developed and/or developing countries. Although panel data are informative and have great degrees of freedom, spatial dependence is a problematic aspect because the cross-sectional units are not randomly sampled in many panel data sets. Spatial correlations are important for assessing the impact of economic growth on environmental quality (Anselin, 2001; Giacomini and Granger, 2004). On the one hand, many subjects about environmental issues are inherently spatial. On the other hand, countries interact strongly with one another through various channels, such as trade, technological diffusion, capital inflows, and common political, economic and environmental policies (Ramirez and Loboguerrero, 2002). Disregarding spatial dependencies may lead to incorrect inferences and poor model performance, and ultimately to incorrect conclusions. This limitation has been recognized by scholars, such as Rupasingha et al. (2004), who incorporated spatial correlation into the analysis of the relationship between per capita income and toxic pollution in US counties. Subsequently, the spatial econometric analysis gradually prevailed in air pollution studies (Maddison, 2006). Therefore, spatial dependence or spatial autocorrelation should be taken into account when assessing the relationship between environmental pollution and economic growth.

However, to the best of our knowledge, no research has employed spatial econometric methods to examine the relationship between economic development and carbon emission. The objective of this study is to explore the feasibility of applying spatial econometric techniques to analyze the relationships between economic growth and carbon emission by taking into account the spatial dependence factor. This paper addresses the following research issues: (1) Does the Kuznets curve exist between regional economic growth and carbon emission in China over the last decade? (2) What are the determinants of carbon emission? In this study, the carbon emission is limited to the emission from fossil fuels. The remainder of this paper is organized as follows: Section 2 describes the spatial econometric techniques employed in this study and the data used for empirical analysis. Section 3 explains the empirical analysis results, and Section 4 concludes the paper. 


\section{Methods}

\subsection{Carbon Kuznets curve}

The traditional Kuznets curve was mainly used to study the relationship between environmental pollution and economic growth (Robalino-López et al., 2014). The majority of EKCs assumed that the logarithm of national emission per capita has a linear relationship with the logarithms of purchasing power parity GDP per capita and its squared value (Madison, 2006). The inverted U-shaped relationship between economic development and carbon emission was specifically referred to as carbon Kuznets curve (CKC) (Wagner, 2008).

In this study, a log-linear quadratic equation is specified to validate the CKC hypothesis on the relationships between the dependent variable (i.e., carbon emission) and the explanatory variables (i.e., industrial structure evolution, urbanization rate, and level of economic growth and its squared value). The formula used is given as:

$$
C E_{i t}=\alpha_{0}+\alpha_{1}(\ln E G)_{i t}+\alpha_{2}(\lg E G)_{i t}{ }^{2}+\alpha_{3}(\ln P S)_{i t}+\alpha_{4}(\ln U R)_{i t}+\varepsilon_{i t}
$$

where:

CE - Carbon Emissions, represented by the total carbon consumption (unit: 10,000 tons).

UR - Urbanization Rate, represented by the percentage of permanent resident population (unit: \%).

EG - Gross Domestic product per area unit, representing the level of economic development (unit: RMB 100,000 Yuan $/ \mathrm{km}^{2}$ ). All GDP data of different years are converted based on the constant price index in 2000.

PSI - Proportion of Secondary Industry, represented by the GDP ratio of secondary industry (unit: \%).

In addition, $a$ represents a coefficient, $i$ represents the region being estimated, $t$ represents the sampling year, and $\varepsilon$ represents the vector of the residuals.

Based on the sample size and the significance level, the relationship between per area unit carbon emission and economic growth is explained as follows: If $a_{2}=a_{1}=0$, economic growth has no relationship with carbon emission. If $a_{2}=0$ and $a_{1}>0$, carbon emission has a linear relationship with economic growth. If $a_{1}>0$ and $a_{2}<0$, carbon emission has an inverted U-shaped relationship with economic growth, which indicates the existence of the CKC. If $a_{1}<0$ and $a_{2}>0$, carbon emission has a positive U-shaped relationship with economic growth. The turning point is $-a_{1} / 2 a_{2}$. 


\subsection{Carbon emission from energy consumption}

Due to the lack of widely accepted calculation methods for anthropogenic carbon emissions in China, an energy carbon emission model was used to calculate carbon emission by combining the measurements from IPCC (IPCC, 2007; Parry, 2007; Solomon, 2007). The $\mathrm{CO}_{2}$ emission was calculated using the following formula:

$$
p=\sum_{i=1}^{8} p_{i}=\sum_{i=1}^{8} S_{i} * F_{i}^{*} M_{i}
$$

where $p$ is the total amount of carbon emission; $i$ denotes the different energy types, including coal (coal and coke), oil (crude oil, diesel, gasoline, kerosene, and fuel oil), and natural gas; $S_{i}$ is the standard coal coefficient of energy type $i ; M_{i}$ is the consumed amount of energy type $i$; and $F_{i}$ is the carbon emission coefficient of energy type $i$. This study adopted the average values of the carbon emission coefficients of coal, oil, and natural gas, which were calculated using the approach of Chuai et al. (2015).

The data of the carbon emission coefficients of coal, oil, and natural gas were obtained from the following institutions: The U.S. Energy Information Administration (EIA) and The U.S. Department of Energy (DOE) of USA, Japan Energy Economy Research Institute, National Science and Technology Commission of China Climate Change Programs, Chinese Academy of Engineering, and Greenhouse Gas Control Project of the National Environmental Protection Administration of China.

Table 1: Carbon emission coefficients and standard coal coefficients of major energy types

\begin{tabular}{|l|c|c|}
\hline \multicolumn{1}{|c|}{ Energy } & $\begin{array}{c}\text { Carbon emission coefficient } \\
(\mathrm{t} / \mathrm{t})\end{array}$ & $\begin{array}{c}\text { Standard coal coefficient } \\
(\mathrm{kg} / \mathrm{kg})\end{array}$ \\
\hline Coal & 0.711 & 0.714 \\
\hline Coke & 0.855 & 0.971 \\
\hline Crude oil & 0.586 & 1.429 \\
\hline Gasoline & 0.554 & 1.471 \\
\hline Diesel & 0.592 & 1.457 \\
\hline Kerosene & 0.571 & 1.471 \\
\hline Fuel oil & 0.619 & 1.529 \\
\hline Natural gas & 0.418 & 1.33 \\
\hline
\end{tabular}

Source: Authors' calculations

The adopted average coefficient values for coal, oil, and natural gas carbon emissions are listed in Table 1. 


\subsection{Spatial fixed-effect models}

A spatial panel approach was used to analyze the relationship between the economic growth and carbon emission in China. The employed spatial correlation models include spatial autoregressive (SAR) model and spatial error regression (SER) model. Generally, when regression analysis is limited to certain individuals (e.g., China's provincial administrative units), the fixed-effects model exhibits higher accuracy than the random-effects model. Here the fixed-effects model refers to regression with a different intercept for each individual, while the randomeffects model assumes the coefficients as random variables (Borenstein et al., 2009; Menegaki, 2011).

A spatial autoregressive structure can be combined with a conventional regression model to produce a spatial extension of the linear regression model, which is called the SAR model (LeSage et al., 2009). The SAR fixed-effects model based on Equation (1) is given as follows (Aneslin, 1998):

$\ln C E_{i t}=\alpha_{0}+\alpha_{1}(\ln E G)_{i t}+\alpha_{2}(\ln E G)_{i t}{ }^{2}+\alpha_{3}(\ln P S I)_{i t}+\alpha_{4}(\ln U R)_{i t}+\rho W(\ln C E)_{i t}+\varepsilon_{i t}$

where $W$ represents a weighting matrix and $\rho$ is a spatial autocorrelation coefficient, which reflects the value and direction of the spatial correlation. The definitions of the notations are the same as those in Equation (1).

The spatial error regression model used in this study takes the following form, also built under the assumption of fixed-effect:

$$
\begin{aligned}
& \ln C E_{i t}=\alpha_{0}+\alpha_{1}(\ln E G)_{i t}+\alpha_{2}(\ln E G)_{i t}{ }^{2}+\alpha_{3}(\ln P S I)_{i t}+\alpha_{4}(\ln U R)_{i t}+\varepsilon_{i t} \\
& \varepsilon_{i t}=\lambda W \varepsilon_{j t}+\gamma_{i t}
\end{aligned}
$$

where $\lambda$ reflects the spatial dependence of the region being estimated on neighboring samples and $\gamma$ is the residual obeying a normal distribution. The definitions of the other notations are the same as those in above Equations (1) and (3).

\subsection{Economic spatial weighting matrix}

The traditional geographic weighting matrix under the Rook adjacent decision abides by the following rules: 1) the two regions with a common border is considered adjacent; and 2) if the region $i$ is adjacent to region $j$, then $W_{i j}$ is 1 ; otherwise, $W_{i j}$ is 0 . The following economic spatial weighting matrix proposed by Lin (2006) was employed in this study to account for the interactions among the regional economies and to improve the model accuracy: 


$$
\begin{aligned}
& W=w^{*} E_{i j} \\
& \overline{Y_{i}}=\frac{1}{13} \sum_{t=2000}^{2012} Y_{i t}=\left\{\begin{array}{ll}
\frac{1}{\left|\bar{Y}_{i}-\bar{Y}_{j}\right|} & \text { if } i \neq \\
0, & \text { if } i=j
\end{array},\right.
\end{aligned}
$$

where $W$ reflects the weight, $w$ reflects the traditional geographic weighting matrix, $E_{i j}$ reflects the economic matrix, $Y$ and $\bar{Y}$ are the gross product in a certain year and the average gross product, respectively. The definitions of other notations are the same as those in Equation (1).

\section{Empirical data and analysis}

\subsection{Empirical data}

Based upon Wang et al. (2014), in this study $\mathrm{CO}_{2}$ emissions for 30 provinces in China (The data for Tibet are not available for most years) from 2000 to 2012 were calculated. Energy consumption data were obtained from China Energy Statistical Yearbook (2001-2013), and the other data were obtained from China Statistical Yearbook (2001-2013).

In order to obtain appropriate carbon emission coefficients, carbon emissions from major fossil fuel energy sources, including coal (coal and coke), oil (crude oil, diesel, gasoline, kerosene, and fuel oil), and natural gas were calculated. The economic growth level was measured by GDP per unit of land area. Compared with per capita GDP that was widely used in other studies, GDP per unit of land area can better indicate the true economic growth level and the degree of land-use intensity (Lichtenberg \& Ding, 2009). To ensure comparability and eliminate the influences of inflation and other factors, the data of GDP per unit of land area in different regions were converted based on the constant price index in 2000 .

\subsection{Spatial autocorrelation test}

EViews 6.0 (Econometrics Views, Quantitative Micro Software, 2007) was used to evaluate the traditional fixed-effect model via the least squares dummy variable (LSDV) method. Table 2 shows the results.

The Durbin-Watson value in Table 2 indicates the existence of spatial autocorrelation in the data (Bohannon, Wang \& Gershon, 2015). Thus, the traditional regression model may yield biased estimates based on the spatially correlated data. 
Table 2: Estimated results using the least squares dummy variable method

\begin{tabular}{|c|c|c|}
\hline Variable & Coefficient & t-statistic \\
\hline Constant & $7.6915^{* * *}$ & 26.5973 \\
\hline $\operatorname{Ln}(\mathrm{EG})$ & $0.7200^{* * *}$ & 32.1069 \\
\hline $\operatorname{Ln}\left(E^{2}\right)$ & $-0.0232 * * *$ & -7.1531 \\
\hline $\operatorname{Ln}(\mathrm{PSI})$ & $0.6072 * * *$ & 8.0971 \\
\hline $\operatorname{Ln}(\mathrm{UR})$ & $0.3604 * * *$ & 3.8894 \\
\hline Durbin-Watson & 0.6513 & \\
\hline $\mathrm{R}^{2}$ & 0.9924 & \\
\hline Log-Likelihood & 276.7795 & \\
\hline F-statistic & 1421.477 & \\
\hline Spatial correlation test & $\mathrm{MI} / \mathrm{DOF}^{\mathrm{a}}$ & Statistic \\
\hline Moran's I & 0.2839 & $7.7300^{* * *}$ \\
\hline LM (lag) & 1 & $10.1349 * * *$ \\
\hline robust LM (lag) & 1 & $21.1064 * * *$ \\
\hline LM (err) & 1 & 1.0733 \\
\hline robust LM (err) & 1 & $12.0448 * * *$ \\
\hline Hausman test & 13 & $382.1800 * * *$ \\
\hline
\end{tabular}

Note: $* * *$, and $* * *$ denote significance at $10 \%$ level, $5 \%$ level, and $1 \%$ level, respectively. a) Moran I and Degree of Freedom

Source: Authors' calculations

Therefore, the relationship between economic growth and carbon emission is better analyzed based on the SAR or SER model by maximum-likelihood estimation. The Lagrange multipliers (LM) test from ordinary least squares can help decide whether or not SER or SAR is a better model for the estimation (Elhorst, 2005).

Table 3: Estimated results for different fixed-effects types of the spatial autoregressive model

\begin{tabular}{|l|r|r|r|r|r|r|r|r|}
\hline \multirow{2}{*}{ Variable } & \multicolumn{2}{|c|}{ No-fixed-effects } & \multicolumn{2}{c|}{ Spatial fixed-effects } & \multicolumn{2}{c|}{$\begin{array}{c}\text { Time period } \\
\text { fixed-effects }\end{array}$} & \multicolumn{2}{c|}{$\begin{array}{c}\text { Spatial and time } \\
\text { period fixed-effects }\end{array}$} \\
\cline { 2 - 12 } & \multicolumn{1}{|c|}{ Coeff. } & \multicolumn{1}{c|}{ t-value } & \multicolumn{1}{c|}{ Coeff. } & t-value & \multicolumn{1}{c|}{ Coeff. } & t-value & \multicolumn{1}{c|}{ Coeff. } & t-value \\
\hline Ln(EG) & $0.6912 * * *$ & 22.3256 & $0.6963 * * *$ & 12.3215 & $0.8058 * * *$ & 27.0728 & $0.5033 * * *$ & 4.2340 \\
\hline $\operatorname{Ln}\left(\mathrm{EG}^{2}\right)$ & 0.0033 & 0.4254 & $-0.0225 * * *$ & -4.3503 & $-0.0128 *$ & -1.8217 & $-0.0129 * * *$ & -4.0900 \\
\hline $\mathrm{Ln}(\mathrm{PSI})$ & $1.9093 * * *$ & 25.9378 & $0.6182 * * *$ & 6.6517 & $0.8548 * * *$ & 6.6158 & $0.6312 * * *$ & 6.5866 \\
\hline $\mathrm{Ln}(\mathrm{UR})$ & -0.1971 & -1.5020 & $0.3485 * * *$ & 0.5767 & 0.1408 & 1.1468 & $0.2829 * *$ & 2.2439 \\
\hline$\rho$ & $0.2070 * * *$ & 7.2502 & 0.0400 & 0.7150 & 0.0016 & 0.0484 & $0.0280 * * *$ & 1.3060 \\
\hline $\mathrm{R}^{2}$ & 0.8562 & & 0.9925 & & 0.8884 & & 0.9936 & \\
\hline $\log$-likelihood & -300.4639 & & 276.9253 & & -248.8723 & & 298.4561 & \\
\hline
\end{tabular}

Note: $* * *$, and $* * *$ denote significance at $10 \%$ level, $5 \%$ level, and $1 \%$ level, respectively.

Source: Authors' calculations 
Table 2 shows the following: 1) the robust LM test for spatial lag is more significant than the robust LM test for spatial error. 2) The LM test for spatial lag is significant, but the LM test for spatial error is not. 3) Moran's I statistic is statistically significant and higher than the zero value. 4) The result of Hausman test rejects the null hypothesis of no fixed effects. Given these results, a spatial autoregressive fixedeffects model was selected for further estimation.

The fixed-effect can be further divided into four types: no fixed-effects, spatial fixed-effects, time period fixed-effects, and spatial and time period fixed-effects models. The four possible fixed-effects types of the SAR fixed-effects model were evaluated with MATLAB. Table 3 shows the estimated results.

Table 4: Estimated results for different fixed-effects types of the spatial error regression model

\begin{tabular}{|l|r|r|r|r|r|r|r|r|}
\hline \multicolumn{1}{|c|}{ Variable } & \multicolumn{2}{|c|}{ No-fixed-effect } & \multicolumn{2}{c|}{ Spatial fixed-effect } & \multicolumn{2}{c|}{$\begin{array}{c}\text { Time period } \\
\text { fixed-effect }\end{array}$} & \multicolumn{2}{c|}{$\begin{array}{c}\text { Spatial and time } \\
\text { period fixed-effect }\end{array}$} \\
\hline & \multicolumn{1}{c|}{ Coeff. } & \multicolumn{1}{c|}{ t-value } & \multicolumn{1}{c|}{ Coeff. } & \multicolumn{1}{c|}{ t-value } & \multicolumn{1}{c|}{ Coeff. } & t-value & \multicolumn{1}{c|}{ Coeff. } & t-value \\
\hline $\mathrm{Ln}(\mathrm{EG})$ & $0.8465 * * *$ & 30.8214 & $0.7352^{* * *}$ & 19.4642 & $0.8482 * * *$ & 34.0835 & $0.5312 * * *$ & 3.9375 \\
\hline $\mathrm{Ln}\left(\mathrm{EG}^{2}\right)$ & $0.0142 * * *$ & 1.6062 & $-0.0279 * * *$ & -5.1284 & -0.0018 & -0.2424 & $-0.0189 * * *$ & -4.3790 \\
\hline $\mathrm{Ln}(\mathrm{PSI})$ & $2.3467 * * *$ & 59.8373 & $0.5907 * * *$ & 6.7790 & $0.5352^{* * *}$ & 5.1333 & $0.6742 * * *$ & 6.7654 \\
\hline $\mathrm{Ln}(\mathrm{UR})$ & $-0.5551^{* * *}$ & -3.8312 & $0.3492 * * *$ & 2.8348 & -0.1143 & -0.8838 & $0.2746 * *$ & 2.2670 \\
\hline$\lambda$ & $0.2199 * * *$ & 3.5495 & $0.1990^{* * *}$ & 3.1747 & $0.5299 * * *$ & 11.2416 & $0.2037 * * *$ & 3.1315 \\
\hline $\mathrm{R}^{2}$ & 0.8372 & & 0.9924 & & 0.8838 & & 0.9933 & \\
\hline $\log$-likelihood & -316.6821 & & 280.4007 & & -215.9279 & & 299.5714 & \\
\hline
\end{tabular}

Note: $*$, **, and $* * *$ denote significance at $10 \%$ level, $5 \%$ level, and $1 \%$ level, respectively.

Source: Authors' calculations

For comparison, the estimated results from the spatial error fixed-effects model are given in Table 4.

\subsection{Spatial econometric analysis}

Comparing the results in Table 3 and Table 4, considering the value of the loglikelihood statistic and goodness-of-fit, spatial autoregressive model has better estimate the effect, so we choose SAR to make the spatial regression analysis.

The statistical analysis results show that the panel analysis approach is effective. Almost all estimates in the four cases using both models passed the significance test at $1 \%$ level, indicating that the results are valid. Further evidence proved the need for importing space effects into the model. Moreover, the spatial correlation coefficients $(\rho$ and $\lambda$ ) of spatial and time period fixed-effects models are all positive, and have passed the $5 \%$ significance test. These results indicate that the 
relationship between per area unit GDP and carbon emission has strong spillover effect on neighboring provinces. Specifically, an increase of $1 \%$ in the carbon emission in a neighboring province could lead to an increase of $0.028 \%$ in the carbon emission of a local area. Thus, the carbon emission of a province is not only dependent on its own economic development but also affected by the carbon emissions of its adjacent provinces. In other words, a fluctuation in the carbon emission of a province could result in corresponding changes in its neighboring provinces. This phenomenon can be attributed to the strong economic ties among provinces. At present, however, carbon emissions from individual provinces were merely evaluated based on their own achievements in terms of economic growth. Implementing the new evaluation system may cause the provinces to compete in controlling carbon emissions while developing their respective economies after the Twelfth Five-Year Plan of China.

In addition, Table 3 and Table 4 show obvious differences between the results obtained using the SAR model and the SEM model with different assumed fixedeffects. After taking into account the spatial fixed effect or both the spatial fixed effect and the time period fixed effect, almost all the evaluated coefficients become statistically significant at $1 \%$ level. The values of the $\mathrm{R}^{2}$ and log-likelihood are obviously improved. The models, therefore, are rendered more accurate when the aforementioned fixed-effects are taken into consideration during the process of evaluating the $\mathrm{CKC}$ in China.

\section{Results and discussion}

As shown in the last column in Table 3, the coefficient of secondary industry proportion is positive and, where a $1 \%$ increase in the secondary industry will lead to an increase of carbon emission by $0.6312 \%$. Thus, the inverted U-shaped Kuznets curve is closely related to industrial structure. According to the stages of economic growth proposed by Rostow (Rostow, 1990), the secondary industry is the key driving force of economic development during the stages of taking-off and driving-to-maturity, which is the case in China at present. The main problems caused by industrialization are overexploitation of resources, environmental issues, and carbon emissions. Due to the highly efficient industrial development and the trend of going green, the industrial development in China is eliminating highpolluted and low-efficient production lines and is moving toward realizing internal organization optimization.

China's economic development follows the trend of moving from a high consumption toward the stage of pursuing a high-quality life. With adjustment and optimization of the industrial structure, the proportion of the secondary industry will become stable or show a downward trend, whereas the tertiary industry as the 
major industry will become increasingly important. The development of advanced technologies and service industries will also alleviate the pressure of carbon emissions and promote a green economy.

Urbanization rate is statistically significant at 5\% level. This result may be due to the following reasons: 1) The urbanization process results in not only strong population migration but also economic restructuring and industrial structure optimization. 2) Large-scale investments in urban infrastructure construction will ultimately lead to an enormous energy consumption. 3) Urbanization will inevitably lead to a rapid increase in carbon-intensive consumption products, such as steel, cement, and glass.

\subsection{Inverted U-shaped Kuznets curve analysis}

Based on the estimated results, the coefficient of $\ln (E G)$ is 0.5033 , and the coefficient of $\ln \left(\mathrm{EG}^{2}\right)$ is -0.0129 . These results indicate that the relationship between carbon emission and economic growth tends to follow the inverted U-shaped Kuznets curve. Therefore, this study preliminarily validated the CKC hypothesis in China: After the inflection point appears at 279.91 million Yuan per area unit GDP (at a comparable price in 2000), carbon emission begins to decrease with the increasing level of economy, as shown in Figure 1 with the turning point being 19.45. Developed cities like Shanghai passed the turning point in 2011 or so.

Figure 1: Kuznets Curve for carbon emission and economic growth in China

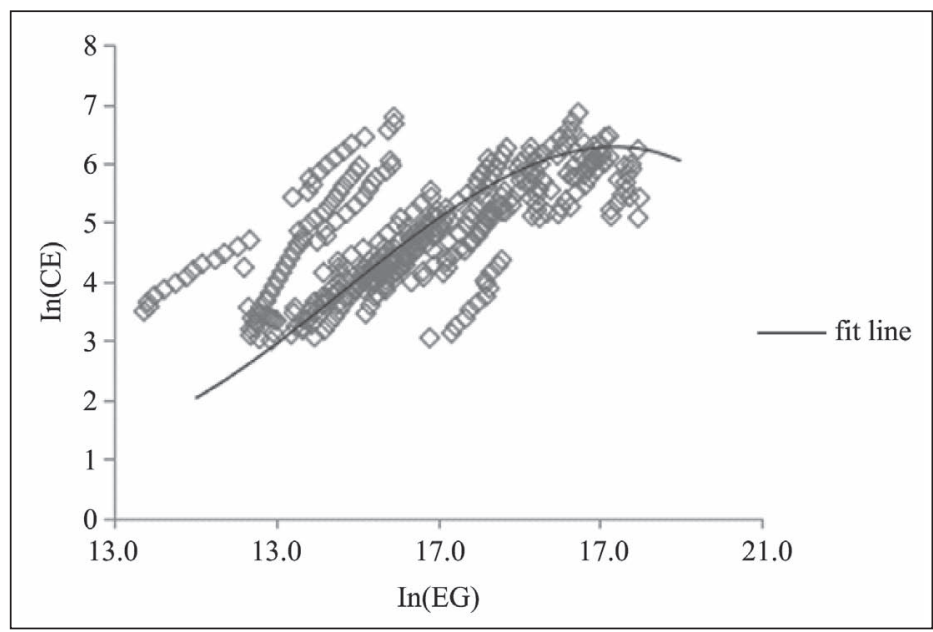

Note: CE means Carbon emission with a unit of 1000 tons; EG means GDP per area unit, with a unit of RMB 100,000 Yuan $/ \mathrm{km}^{2}$.

Source: Authors' calculations 
Although not all provinces and cities in the whole country conform to the model in Figure 1, we can approximately confirm to some extant the existence of Kuznets curve relationship between carbon emissions and regional economic growth.

Figure 2: Scatter diagrams for carbon emission and economic growth in Tianjin and Zhejiang

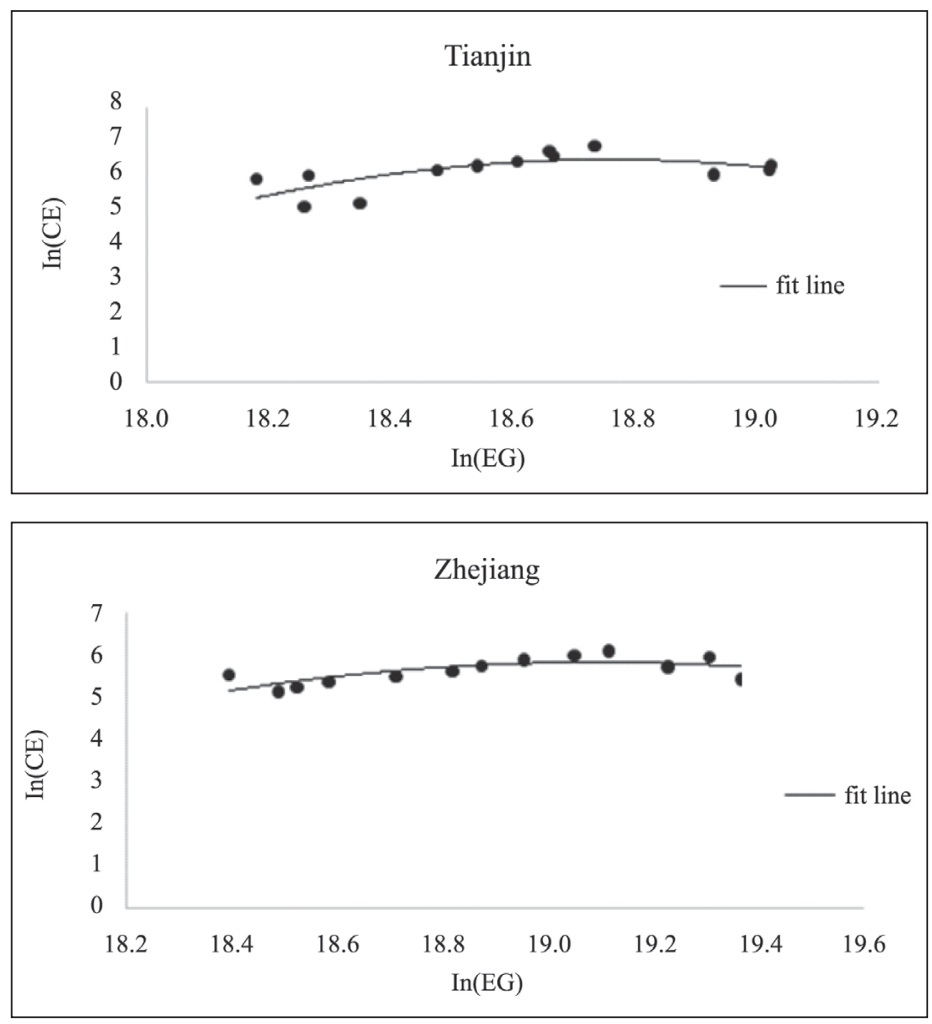

Note: CE means Carbon emission with a unit of 1000 tons; EG means GDP per area unit, with a unit of RMB 100,000 Yuan $/ \mathrm{km}^{2}$.

Source: Authors' calculations

The scatter diagrams of carbon emission and economic growth for Tianjin city and Zhejiang province (Fig. 2) further show the tendency of Kuznets Curve relationship between carbon emission and economic growth in China. 


\section{Conclusions}

Spatial econometric techniques provide a means to explore the question of whether or not the carbon emission of a province depends on the characteristics of its neighboring provinces. Using these techniques, the CKC hypothesis in China's carbon emission (from fossil fuels) and economic growth from 2000 to 2012 was tested with the annual statistical data at the provincial level. This study shows that the relationship between carbon emission and economic growth in China has indicated the tendency to follow the inverted U-shaped Kuznets curve, thus preliminarily confirming the CKC hypothesis in China. Specifically, results from this study show that (1) a significant spatial correlation between carbon emission and economic growth exists, that is, the carbon emission of a province is affected by its adjacent provinces; (2) an increase of $1 \%$ in the carbon emission in a neighboring province could lead to an increase of $0.028 \%$ in the carbon emission in a local province; (3) both industrial structure and urbanization rate have certain impacts on carbon emission while the former is the key determinant; and (4) when economic growth reaches 279.91 million Yuan per area unit GDP (at a comparable price of 2000), the contradiction between economic growth and carbon emission will be gradually alleviated. Currently, only a few of the well-developed provinces or provincial-level cities in China, such as Tianjin, Beijing, Shanghai, and Jiangsu, have reached this inflection point.

Based on above conclusions derived from this study, the following policy implications may be obtained:

First, industrial structure is the leading key factor in carbon emission. Therefore, governments should be encouraged to eliminate some heavy and low-efficient industries at the national or provincial level. Furthermore, governments should promote high-tech industry and improve energy efficiency by implementing some policies that can stimulate industrial structure optimization.

Second, urbanization has a significant impact on energy consumption and carbon dioxide emission. Therefore, related policies that can reduce the speed of urbanization should be enacted. Currently, the speed of urbanization in China is extremely fast. Controlling the urbanization speed can promote green energy consumption and reduce carbon emission.

Finally, GDP should be eliminated from the indices used in assessing local government performance. Although more than 70 counties stopped using GDP as an indicator for performance evaluation by the end of August 2014, an increased effort should be made to encourage other countries to follow. An appropriate regulatory mechanism should also be established.

Further studies are required to enable formulation of a reasonable regional economic growth plan that can promote energy conservation while reduce carbon emission. 


\section{References}

Anselin, L. (2001) "Spatial effects in econometric practice in environmental and resource economics", American Journal of Agricultural Economics, Vol. 83, No. 3, pp. 705-710, doi: 10.1111/0002-9092.00194.

Anselin, L., Bera, A. (1998) "Spatial dependence in linear regression models with an introduction to spatial econometrics", Ullah A, Giles DE (eds) Handbook of applied economic statistics, Marcel Dekker, New York, pp. 237-289.

Apergis, N., Payne, J.E. (2009) " $\mathrm{CO}_{2}$ emissions, energy usage, and output in Central America”, Energy Policy, Vol. 37, No. 8, pp. 3282-3286, doi: 10.1016/j.enpol. 2009.03.048.

Azomahou, T., Laisney, F., Phu, N.V. (2006) "Economic development and $\mathrm{CO}_{2}$ emissions: a non parametric panel approach", Journal of Public Economics, Vol. 90, No. 6, pp. 1347-1363, doi: 10.1016/j.jpubeco.2005.09.005.

Barnett, T.P., Adam, J.C., Lettenmaier, D.P. (2005) "Potential impacts of a warming climate on water availability in snow dominated regions", Nature, Vol. 438, No. 7038, pp. 303-309, doi: 10.1038/nature04141.

Bhattarai, M., Hammig, M. (2001) "Institutions and the Environmental Kuznets Curve for deforestation: A cross-country analysis for Latin America, Africa, and Asia", World Development, Vol. 29, No. 6, pp. 995-1010, doi: 10.1016/S0305750X(01)00019-5.

Bohannon, R.W., Wang, Y.C., Gershon, R.C. (2015) "Two-minute walk test performance by adults 18 to 85 years: Normative values, reliability, and responsiveness", Archives of physical medicine and rehabilitation, Vol. 96, No. 3, pp. 472-477, doi: 10.1016/j.apmr.2014.10.006.

Borenstein, M., Hedges, L.V., Higgins, J., Rothstein, H.R. (2009) "Fixed-Effect Model", Introduction to meta-analysis, pp. 63-67.

Carson, R.T. (2010) "The environmental Kuznets curve: seeking empirical regularity and theoretical structure", Review of Environmental Economics and Policy, Vol. 4, No. 1, pp. 3-23, doi: 10.1093/reep/rep021.

Chuai, X.W., Huang, X.J., Wang, W.J., Zhao, R.Q. (2015) "Land use, total carbon emissions change and low carbon land management in Coastal Jiangsu, China", Journal of Cleaner Production, Vol. 103, No. 15, pp. 77-86, doi: 10.1016/j. jclepro.2014.03.046.

Culas, R.J. (2007) "Deforestation and the environmental Kuznets curve: an institutional perspective", Ecological Economics, Vol. 61, No. 2-3, pp. 429-437, doi: 10.1016/j.ecolecon.2006.03.014.

Deng, X.Z., Han, J.Z., Zhang, J.Y., Zhao, Y.H. (2009) "Management strategies and their evaluation for carbon sequestration in cropland", Agriculture Science \& Technology, Vol. 10, No. 5, pp. 134-139, (in Chinese). 
Dinda, S. (2001) "A note on global EKC in case of $\mathrm{CO}_{2}$ emission", Economic Research Unit, Indian Statistical Institute, Kolkata, Mimeo.

Elhorst, J.P. (2005) "Unconditional maximum likelihood estimation of linear and log-linear dynamic models for spatial panels", Geographical Analysis, Vol. 37, pp. 85-106, doi: 10.1111/j.1538-4632.2005.00577.x.

Fodha, M., Zaghdoud, O. (2010) "Economic growth and pollutant emissions in Tunisia: an empirical analysis of the environmental Kuznets curve", Energy Policy, Vol. 38, No. 2, pp. 1150-1156, doi: 10.1016/j.enpol.2009.11.002.

Fosten, J., Morley, B., Taylor, T. (2012) "Dynamic misspecification in the environmental Kuznets curve: evidence from $\mathrm{CO}_{2}$ and $\mathrm{SO}_{2}$ emissions in the United Kingdom", Ecological Economics, Vol. 76, pp. 25-33, doi: 10.1016/j. ecolecon.2012.01.023.

Galbraith, J. (2007) "Global inequality and global macroeconomics", Journal of Policy Modeling, Vol. 29, No. 4, pp. 587-607, doi: 10.1016/j.jpolmod.2007.05.008.

Giacomini, R., Granger, C.W.J. (2004) "Aggregation of space-time processes", Journal of Econometrics, Vol. 118, No. 1-2, pp. 7-26, doi: 10.1016/S03044076(03)00132-5.

Grossman, G.M., Krueger, A.B. (1995) "Economic growth and the environment", Quarterly Journal of Economics, Vol. 110, No. 2, pp. 353-377, doi: 10.2307/ 2118443.

He, C., Huang Z., Ye, X. (2013) "Spatial heterogeneity of economic development and industrial pollution in urban China", Stochastic Environmental Research \& Risk Assessment, Vol. 28, No. 4, pp. 767-781. doi: 10.1007/s00477-013-0736-8.

He, J., Richard, P. (2010) "Environmental Kuznets curve for $\mathrm{CO}_{2}$ in Canada", Ecological Economics, Vol. 69, No. 5, pp. 1083-1093. doi: 10.1016/j. ecolecon.2009.11.030.

IPCC. Fourth Assessment of Working Group II. (2007) "Climate change 2007: Climate change impacts, adaptation and vulnerability. Summary for policymakers", Geneva: IPCC. IPCC (Intergovernmental panel on Climate Change), Vol. 213, pp. 79-128.

Iwata, H., Okada, K., Samreth, S. (2010) "Empirical study on the environmental Kuznets curve for $\mathrm{CO}_{2}$ in France: the role of nuclear energy", Energy Policy, Vol. 38, No. 8, pp. 4057-4063. doi: 10.1016/j.enpol.2010.03.031.

Jaiarree, S., Chidthaisong, A., Tangtham, N., Polprasert, C., Sarobol, E., Tyler, S.C. (2011) "Soil organic carbon loss and turnover resulting from forest conversion to maize fields in Eastern Thailand", Pedosphere, Vol. 21, No. 5, pp. 581-590, doi: 10.1016/S1002-0160(11)60160-4.

James L., Robert K.P. (2009) "Introduction to Spatial Econometrics", Taylor \& Francis Group, LLC.

Kaufmann, R.K., Davidsdottir, B., Garnham, S., Pauly, P. (1998) “The determinants of atmospheric $\mathrm{SO}_{2}$ concentrations: Reconsidering the Environmental Kuznets 
Curve", Ecological Economics, Vol. 25, No. 209-220. doi: 10.1016/S09218009(97)00181-X.

Kijima, M., Nishide, K., Ohyama, A. (2010) "Economic models for the environmental Kuznets curve: A survey", Journal of Economic Dynamics and Control, Vol. 34, No. 7, pp. 1187-1201. doi: 10.1016/j.jedc.2010.03.010.

Koop, G., Tole, L. (1999) "Is there an Environmental Kuznets Curve for deforestation?", Journal of Development Economics, Vol. 58, No. 1, pp. 231-244, doi: 10.1016/S0304-3878(98)00110-2.

Lal, R. (2002) "Soil carbon dynamics in cropland and rangeland", Environmental Pollution, Vol. 116, No. 3, pp. 353-362, doi: 10.1016/S0269-7491(01)00211-1.

Lean, H.H., Smyth, R. (2010) " $\mathrm{CO}_{2}$ emissions, electricity consumption and output in ASEAN", Applied Energy, Vol. 87, No. 6, pp. 1858-1864. doi: 10.1016/j. apenergy.2010.02.003.

Leitao, A. (2010) "Corruption and the environmental Kuznets curve: Empirical evidence for sulfur original research article", Ecological Economics, Vol. 69, No. 11, pp. 2191-2201, doi: 10.1016/j.ecolecon.2010.06.004.

Lichtenberg, E., Ding, C. (2009) "Local officials as land developers: Urban spatial expansion in China", Journal of Urban Economics, Vol. 66, No. 1, pp. 57-64, doi: 10.1016/j.jue.2009.03.002.

Lin, K.P., Long, Z.H., Wu, M. (2006) "A spatial investigation of $\sigma$-convergence in China”, AppliedMicrobiology\&Biotechnology, Vol. 73, No. 1, pp. 27-36. doi: 10.3969/j.issn.1000-3894.2006.04.002.

Maddison, D. (2006) "Environmental Kuznets curves: A spatial econometric approach", Journal of Environmental Economics \& Management, Vol. 51, No. 2, pp. 218-230. doi: 10.1016/j.jeem.2005.07.002.

McPherson, M.A., Nieswiadomy, M.L. (2005) "Environmental Kuznets curve: Threatened species and spatial effects", Ecological Economics, Vol. 55, No. 3, pp. 395-407. doi: 10.1016/j.ecolecon.2004.12.004.

Menegaki, A. N. (2011) "Growth and renewable energy in Europe: A random effect model with evidence for neutrality hypothesis", Energy Economics, Vol. 33, No. 2, pp. 257-263, doi: 10.1016/j.eneco.2010.10.004.

Parry, M.L. (Ed.). (2007) "Climate change 2007-impacts, adaptation and vulnerability: Working group II contribution to the fourth assessment report of the IPCC (Vol. 4)", Cambridge University Press.

Ramirez, M., Loboguerrero, A. (2002) "Spatial dependence and economic growth: evidence from a panel of countries", Borradores de Economia Working Paper. No. 206.

Robalino-López, A., Mena-Nieto, Á. (2014) "Studying the relationship between economic growth, $\mathrm{CO}_{2}$ emissions, and the environmental Kuznets curve in Venezuela (1980-2025)", Renewable and Sustainable Energy Reviews, Vol. 41, pp. 602-614, doi: 10.1016/j.rser.2014.08.081. 
Romero-Avila, D. (2008) "Questioning the empirical basis of the environmental Kuznets curve for $\mathrm{CO}_{2}$ : new evidence from a panel stationarity test robust to multiple breaks and cross-dependence", Ecological Economics, Vol. 64, No. 3, pp. 559-574. doi: 10.1016/j.ecolecon.2007.03.011.

Rostow, W.W. (1990) "The stages of economic growth: A non-communist manifesto", Cambridge university press.

Saboori, B., Sulaiman, J., Mohd, S. (2012) "Economic growth and $\mathrm{CO}_{2}$ emissions in Malaysia: a cointegration analysis of the environmental Kuznets curve", Energy Policy, Vol. 51, No. 4, pp. 184-191, doi: 10.1016/j.enpol.2012.08.065.

Shahbaz, M., Lean, H.H., Shabbir, M.S. (2012) "Environmental Kuznets curve hypothesis in Pakistan: cointegration and Granger causality", Renewable and Sustainable Energy Reviews, Vol. 16, No. 5, pp. 2947-2953, doi: 10.1016/j. rser.2012.02.015.

Solomon, S. (Ed.). (2007) "Climate change 2007-the physical science basis: Working group I contribution to the fourth assessment report of the IPCC (Vol. 4)", Cambridge University Press.

Stern, D.I. (2004) "The rise and fall of the environmental Kuznets curve", World development, Vol. 32, No. 8, pp. 1419-1439. doi: 10.1016/j.worlddev.2004.03.004.

Stern, D.I. (2012) "Modeling international trends in energy efficiency", Energy Economics, Vol. 34, No. 6, pp. 2200-2208. doi: 10.1016/j.eneco.2012.03.009.

Stern, D.I. (2014) "The environmental Kuznets curve: A primer", Centre for Climate Economics \& Policy, Crawford School of Public Policy, The Australian National University.

Stern, D.I. (1998) "Progress on the environmental Kuznets curve?", Environment and development economics, Vol. 3, No. 2, pp. 173-196. doi: 10.1017/ S1355770X98000102.

Wagner, M. (2008) "The carbon Kuznets curve: A cloudy picture emitted by bad econometrics?", Resource and Energy Economics, Vol. 30, No. 3, pp. 388-408. doi: 10.1016/j.reseneeco.2007.11.001.

Wallace, J.M., Held, I.M., Thompson, D.W.J., Trenberth, K.E., Walsh, J.E. (2014) "Global warming and winter weather", Science, Vol. 343, pp. 729-730. doi: 10.1126/science.343.6172.729.

Wang, S., Fang, C., Guan, X., Pang, B., Ma, H. (2014) "Urbanisation, energy consumption, and carbon dioxide emissions in China: A panel data analysis of China's provinces", Applied Energy, Vol. 136, No. C, pp. 738-749. doi: 10.1016/j.apenergy.2014.09.059.

Zhao, R., Huang, X., Zhong, T., Peng, J. (2011) "Carbon footprint of different industrial spaces based on energy consumption in China", Journal of Geographical Sciences, Vol. 21, No. 2, pp. 285-300. doi: 10.1007/s11442-0110845-6. 


\title{
Ekonomski rast i emisija ugljika u Kini: Kuznetsova krivulja prostorne ekonometrije $^{1}$
}

\author{
Hengzhou Xü, Chuanrong Zhang ${ }^{3}$, Weidong Li $i^{4}$, Wenjing Zhang ${ }^{5}$, Hongchun Yin ${ }^{6}$
}

\begin{abstract}
Sažetak
Gospodarski razvoj uvelike je pridonio povećanju emisije $\mathrm{CO}_{2}$. Ova studija koristi prostorne ekonometrijske modele za istraživanje odnosa između gospodarskog rasta i emisije ugljika u Kini s podacima iz 30 pokrajina Kine u razdoblju od 2000. do 2012. godine. Rezultati pokazuju da tijekom posljednjeg desetljeća odnos emisije ugljika $i$ gospodarskog rasta u Kini ima tendenciju razvoja prema inverznoj krivulji U-oblika, približno potvrđujući hipotezu Kuznetsove krivulje emisije ugljika u Kini. Postoji značajna prostorna povezanost između emisije ugljika i ekonomskog rasta, što implicira da na emisiju ugljika u pokrajini može utjecati gospodarski rast u susjednim pokrajinama. Nakon što je ekonomski rast dosegnuo omjer od 279,91 milijuna Yuan $/ \mathrm{km}^{2}$ BDP-a (usporediva cijena u 2000. godini), kontradikcija između gospodarskog rasta i emisije ugljika počinje se postupno ublažavati. Ovi rezultati pružaju nove uvide i vrijedne informacije kako reducirati emisije ugljika u Kini.
\end{abstract}

Ključne riječi: emisija ugljika, Kuznetsova krivulja okoliša, promjena namjene zemljišta, prostorna ekonometrija

JEL klasifikacija: Q56

1 Ovo istraživanje provedeno je uz financijsku potporu Nacionalne zaklade za društvene znanosti Kine: "Evaluation on Effect of Rural Land Rights Confirmation Policy Implementation under the Perspective of Household Livelihood Diversity - Procjena utjecaja implementacije politike potvrdivanja ruralnih zemljišnih prava u perspektivi raznolikosti življenja domaćinstava" (Grants: 17BJY090) and Humanities and Social Sciences projects of the Ministry of Education - i Projekata Humanističkih i društvenih znanosti Ministarstva obrazovanja "Farmers' behavior response to farmland ownership and its impact on rural land transfer - Reakcija poljoprivrednika na vlasništvo poljoprivrednog zemljišta i njegov utjecaj na ruralni prijenos zemljišta" (Grants: 16YJC630149).

2 Izvanredni profesor, Tianjin University, College of Management and Economics, No. 92 Weijin Road, Tianjin, P.R. Kina. Znanstveni interes: resursna ekonomija i politika. Tel.: +086 22 27403971.E-mail:xuhengzhou@163.com.

3 Redoviti profesor, University of Connecticut, Department of Geography, Storrs, CT 062694148, USA. Znanstveni interes: promjena namjene zemljišta i politika. Tel.: +0862227403971. E-mail: Cindyzhang2003@126.com.

${ }^{4}$ Redoviti profesor, University of Connecticut, Department of Geography, Storrs, CT 062694148, USA. Znanstveni interes: promjena namjene zemljišta i politika. Tel.: +0862227403971. E-mail:weidongli2003@126.com.

5 Magistrand, Tianjin University, College of Management and Economics, No. 92 Weijin Road, Tianjin, P.R. Kina. Znanstveni interes: promjena namjene zemljišta i politika. Tel.: +08622 27403971.E-mail: wenjingzh@tju.edu.cn.

${ }^{6}$ Izvanredni profesor, Tianjin University, College of Management and Economics, No. 92 Weijin Road, Tianjin, P.R. Kina. Znanstveni interes: resursna ekonomija i politika. Tel.: +08622 27403971.E-mail: hongchunyin2012@163.com (osoba za kontakt). 